\title{
Biochronostratigraphy and paleoenvironment analysis of Neogene deposits from the Pelotas Basin (well 2-TG-96-RS), Southernmost Brazil
}

\author{
WAGNER G. SILVA ${ }^{1,2}$, GEISE S.A. ZERFASS ${ }^{3}$, PAULO A. SOUZA ${ }^{4}$ and JAVIER HELENES ${ }^{5}$ \\ ${ }^{1}$ Instituto Federal de Educação, Ciência e Tecnologia do Rio Grande do Sul, IFRS, \\ Campus Osório, Rua Santos Dumont, 2127, 95520-000 Osório, RS, Brasil \\ ${ }^{2}$ Programa de Pós-Graduação em Geociências, Laboratório de Palinologia Marleni Marques-Toigo, Instituto de Geociências, \\ Universidade Federal do Rio Grande do Sul, Avenida Bento Gonçalves, 9500, 91540-000 Porto Alegre, RS, Brasil \\ ${ }^{3}$ BPA/PDGEO/CENPES/PETROBRAS, Avenida Horácio Macedo, 950, Ilha do Fundão, 21941-915 Rio de Janeiro, RJ, Brasil \\ ${ }^{4}$ Departamento de Paleontologia e Estratigrafia, Instituto de Geociências, Universidade Federal do \\ Rio Grande do Sul, Avenida Bento Gonçalves, 9500, 91540-000 Porto Alegre, RS, Brasil \\ ${ }^{5}$ Departamento de Geología, División de Ciencias de la Tierra, Centro de Investigación Científica y de Educación Superior de \\ Ensenada (CICESE), Km 107, Carretera Tijuana-Ensenada, Ensenada, Baja California, 22860, México
}

Manuscript received on October 31, 2014; accepted for publication on December 8, 2014

\begin{abstract}
This paper presents the integration of micropaleontological (palynology and foraminifera) and isotopic $\left({ }^{87} \mathrm{Sr} r{ }^{86} \mathrm{Sr}\right)$ analysis of a selected interval from the well 2-TG-96-RS, drilled on the onshore portion of the Pelotas Basin, Rio Grande do Sul, Brazil. A total of eight samples of the section between 140.20 and $73.50 \mathrm{~m}$ in depth was selected for palynological analysis, revealing diversified and abundant palynomorph associations. Species of spores, pollen grains and dinoflagellate cysts are the most common palynomorphs found. Planktic and benthic calcareous foraminifera were recovered from the lowest two levels of the section (140.20 and $134.30 \mathrm{~m}$ ). Based on the stratigraphic range of the species of dinoflagellate cysts and sporomorphs, a span age from Late Miocene to Early Pliocene is assigned. The relative age obtained from the ${ }^{87} \mathrm{Sr}{ }^{86} \mathrm{Sr}$ ratio in shells of calcareous foraminifers indicates a Late Miocene (Messinian) correspondence, corroborating the biostratigraphic positioning performed with palynomorphs. Paleoenvironmental interpretations based on the quantitative distribution of organic components (palynomorphs, phytoclasts and amorphous organic matter) throughout the section and on foraminiferal associations indicate a shallow marine depositional environment for the section. Two palynologicals intervals were recognized based on palynofacies analysis, related to middle to outer shelf (140.20 to $128.90 \mathrm{~m}$ ) and inner shelf (115.75 to $73.50 \mathrm{~m}$ ) conditions.
\end{abstract}

Key words: Micropaleontology, Biostratigraphy, Neogene, Pelotas Basin.

\section{INTRODUCTION}

The Pelotas Basin is situated in the southernmost portion of the Brazilian continental margin and was developed as a result of the Gondwana break-up, which originated the South Atlantic Ocean. The stratigraphical evolution of this basin has been

Correspondence to: Wagner Guimarães da Silva E-mail: wagner.guimaraes.silva@gmail.com intensively studied in recent years (Fontana 1990, Villwock and Tomazelli 1995, Castillo et al. 2009, Contreras et al. 2010, Stica et al. 2014).

Additionally, several paleontological studies have been published, mainly focused on taxonomic and paleoenvironmental analysis of foraminifera (e.g., Closs 1967, 1970, Thiesen 1977) and ostracods (e.g., Sanguinetti 1980, Carreño et al. 
1997) as well as certain biostratigraphic studies based on foraminifera and calcareous nannofossils (Gomide 1989, Anjos and Carreño 2004, Coimbra et al. 2009, Guerra et al. 2012). Few palynological contribuitions have been made in pre-Quaternary deposits of this basin (Arai et al. 2006, Premaor et al. 2010, Silva et al. 2011, Fischer et al. 2013). These papers represent recent investigations from subsurface sampling, focusing on age assignments and paleoenvironmental analysis. Dinoflagellate cysts and spore-pollen taxa are the most common palynomorphs recorded by those authors. However, a palynostratigraphical framework of this basin is still needed.

A general biostratigraphic analysis on the Cenozoic strata of the Pelotas Basin was presented by Anjos-Zerfass et al. (2008), which also included ${ }^{87} \mathrm{Sr} /{ }^{86} \mathrm{Sr}$ isotopes data, as a tool for chronostratigraphic purposes. The use of a strontium isotopes stratigraphic framework is a significant resource to calibrate the dates obtained by biostratigraphy, improving the integrated stratigraphic framework of the basin.

This paper presents the results of high-resolution biostratigraphical analysis based on microfossils (palynology and foraminifera) and ${ }^{87} \mathrm{Sr} /{ }^{86} \mathrm{Sr}$ ratios for a Neogene section of this basin, in samples from well 2-TG-96-RS, drilled by the Companhia de Pesquisa de Recursos Minerais (CPRM). Additionally, a palynofacies characterization is presented, as a guide to the paleoenvironmental interpretations.

\section{GEOLOGICAL AND PALEONTOLOGICAL SETTING}

GEOLOGY

The Pelotas Basin, located on the South America continental margin between $28^{\circ} 40^{\prime} \mathrm{S}$ and $34^{\circ} \mathrm{S}$ (Fig. 1a, b), is bounded to the North by the Florianópolis High in Brazil and to the South by the Polonio High in Uruguay (Kowsmann et al. 1974). The Florianópolis High, of volcanic origin, is related to the South Atlantic superplume, that was active during the Cretaceous. The Polonio High is an older feature of the Precambrian Uruguayan Shield basement. Similar to other Brazilian Eastern Margin basins, the Pelotas Basin resulted from the Gondwana break-up and South Atlantic opening since the Aptian (Ojeda 1981, Asmus and Baisch 1983, Conceição et al. 1988, Chang et al. 1992, Cainelli and Mohriak 1999).

The basin area is approximately $210.000 \mathrm{~km}^{2}$, of which $40.000 \mathrm{~km}^{2}$ is onshore. Although the entire section includes sedimentary rocks from the Aptian to the Holocene, on the onshore portion of the basin only deposits of the Quaternary out cropping (Fig. 1a, b). The maximum thickness of the total sedimentary section reaches $12.000 \mathrm{~m}$ (Fontana 1994).

Since the opening of the South Atlantic, the Pelotas Basin received clastic sedimentation as a result of the denudation of adjacent highlands (Villwock 1984). Sucessive sea-level cycles caused the accumulation of a clastic wedge, which was affected only by incipient post-depositional deformation, represented by tilted blocks with strata dipping seaward (Villwock 1984). In general, the entire stratigraphic succession includes a basic transgressive and an upper regressive interval, from the Aptian to Holocene strata (Bueno et al. 2007).

The studied interval is part of the major Paleocene-Holocene regressive supercycle that is composed of proximal siltstones and sandstones assigned to the Cidreira Formation, as well as distal mudstones with some intercalated turbiditic sandstones of the Imbé Formation (Dias et al. 1994, Bueno et al. 2007). The Cidreira Formation deposits prograde into the basin, merging with the Imbé Formation sediments, which were deposited in more distal portions.

\section{PALEONTOLOGY}

Contributions derived from benthic foraminifera and ostracods of the pre-Quaternary sucession are relatively abundant, providing paleoenvironmental 


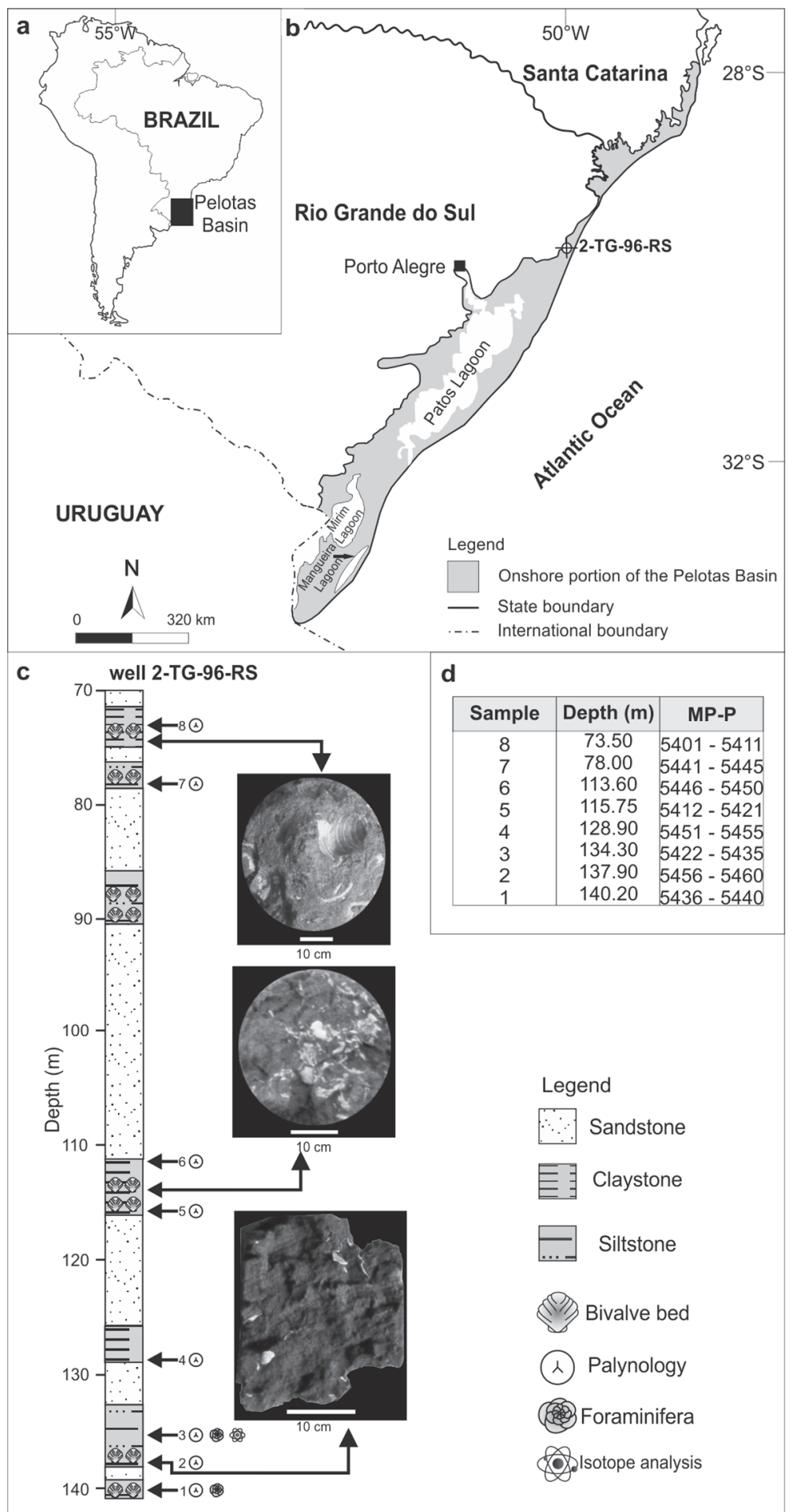

Fig. 1 - Area location and sampling of the well 2-TG-96-RS in Pelotas Basin (a-b). Stratigraphic column of the interval studied, showing the position of micropaleontological and ${ }^{87} \mathrm{Sr} /{ }^{86} \mathrm{Sr}$ isotopes samples analyzed in the present study (c) and list of palynological samples (d) (MP-P refers to the slide collection of the LPMMT/IG/UFRGS). 
interpretations (e.g., Koutsoukos 1982, Carreño et al. 1999, Ceolin et al. 2011). Simões et al. (2008) presented a taxonomy review of brachiopods recorded from some Neogene deposits of the onshore portion. Biostratigraphic data is mainly obtained through the study of planktic foraminifera and calcareous nanofossils (Koutsoukos 1982, Gomide 1989, Anjos and Carreño 2004, Coimbra et al. 2009). Most biostratigraphic information of the Neogene deposits comes from boreholes, drilled in the onshore portion of the basin.

Quaternary deposits reveal a varied fossil content, including vertebrates and microfossils, such as foraminifera, palynomorphs and diatoms (e.g., Closs 1970, Lopes et al. 2010, Macedo et al. 2010, Hermany et al. 2013). Palynological analysis has provided paleoclimate interpretations and paleoenvironmental reconstructions for Quaternary deposits, mainly focusing on the marine influence on the coastal plain of the state of Rio Grande do Sul (Bauermann et al. 2009).

Palynological studies from the pre-Quaternary section (Arai et al. 2006, Premaor et al. 2010, Silva et al. 2011, Fischer et al. 2013) represent a new stage of systematic work developed in recent years. Palynological associations of Late Cretaceous (Arai et al. 2006, Premaor et al. 2010), Paleogene (Fischer et al. 2013) and Miocene/Pleistocene (Silva et al. 2011) ages were presented. Abundant and diversified assemblages of spore-pollen taxa and dinoflagellate cysts, in addition to foraminiferal linings, scolecodonts, and algae species.

\section{MATERIALS AND METHODS}

The well 2-TG-96-RS was drilled by the CPRM on the onshore portion of the Pelotas Basin (2946'12”S/5005'02”W) (Fig. 1a, b). The sedimentary section related to the sampled interval (73.50 to $140.20 \mathrm{~m}$ of depth) consists of $66.7 \mathrm{~m}$ of mudstones, with intercalations of siltstones rich in pelecypods fragments (Ostrea sp. and Anomalocardia spp.) (Fig. 1c). Eight samples were collected from this interval (Fig. 1c), from which palynological data were derived. Foraminiferal specimens were only recovered from two basal levels $(134.30 \mathrm{~m}$ and $140.20 \mathrm{~m}) .{ }^{87} \mathrm{Sr} /{ }^{86} \mathrm{Sr}$ isotope data was obtained from benthic foraminifera shells recorded at $134.30 \mathrm{~m}$ of depth (Fig. 1c).

\section{PALYNOLOGY}

Palynological samples were prepared at the Laboratório de Palinologia "Marleni Marques-Toigo", Departamento de Paleontologia e Estratigrafia in the Instituto de Geociências at Universidade Federal do Rio Grande do Sul (LPMMT/IG/UFRGS), following the conventional method for pre-Quaternary material described by Wood et al. (1996), employing hydrochloric and hydrofluoric acids. Final residues were obtainned by sieving; from wich slides were mounted using the fraction between 20 and 250 $\mu \mathrm{m}$. Fucsina pigment was added to some residues to facilitate taxonomic identification. A total of 56 slides was prepared, which are stored in the LPMMT/IG/UFRGS collection under the code "MP-P" (Fig. 1d). Taxonomical analyses was performed using an microscope Olympus BX-61, with phase contrast and fluorescence light (mercury)

Quantitative data and the ensuing palynofacies analysis were obtained by counting at least 400 particles from each sample which enabled the generation of graphs exhibiting variation in composition of particulate organic matter along the studied section. Quantitative results were processed with Tilia and Tiliagraph softwares (Grimm 1987, 1990). All organic particles were identified and classified in the following categories: continental palynomorphs (pteridophyte and bryophyte spores, gymnosperm pollen, angiosperm pollen, fungi, freshwater algae) and marine (dinoflagellate cysts, foraminiferal linings); phytoclasts (opaque and translucent phytoclasts, cuticles) and amorphous organic matter. The cuticles are represented separately within the translucent phytoclasts due to their abundance in certain levels. 
FORAMINIFERA AND STRONTIUM RATIO $\left({ }^{87} \mathrm{Sr} /{ }^{86} \mathrm{Sr}\right)$

An aliquot of $60 \mathrm{~g}$ of sediments per sample was prepared following the conventional micropaleontological techniques for calcareous microfossils (Thomas and Murney 1985). Foraminiferal shells from 125 and $250 \mu \mathrm{m}$ were hand-picked under an Olympus SZ1145 stereomicroscope. Taxonomic determinations were also supported by employing a scanning electronic microscope JEOL JSM 5800 at the Centro de Microscopia Eletrônica - UFRGS.

Well-preserved specimens of the benthic foraminifera species Nonionella atlantica, Nonionoides grateloupii and Hanzawaia boueana from two samples (134.30 $\mathrm{m}$ and $140.20 \mathrm{~m})$ were separated and ultrasonically cleaned with ultrapure water (Milli-Q) to remove particles adhered to the shells. Strontium ratio $\left({ }^{87} \mathrm{Sr} /{ }^{86} \mathrm{Sr}\right)$ analyses were performed using these selected foraminifera, at the Laboratório de Geologia Isotópica (IG/UFRGS). Isotopic ratios were measured in static mode with a VG Sector 54 multi-collector mass spectrometer. An average of 120 ratios was collected with a 1 -volt ${ }^{88} \mathrm{Sr}$ beam. Strontium ratios were normalized to ${ }^{87} \mathrm{Sr} /{ }^{86} \mathrm{Sr}=$ 0.1194. Measurements are considered for the NBS987 standard ${ }^{87} \mathrm{Sr} /{ }^{86} \mathrm{Sr}=0.710250 \pm 0.000007$. The standard curve used for the age assessment was derived from the database compiled by McArthur et al. (2001) and McArthur and Howarth (2004).

\section{RESULTS}

\section{Micropaleontological Content}

Most of the samples presented palynological associations composed mainly of dinoflagellate cysts and foraminiferal linnings. Twelve species of dinoflagellate cyst belonging to seven genera were identified, as well as eight species of pteridophyte spores, twelve taxa of gymnosperm and angiosperm pollen grains, besides specimens assigned to fungi, acritarch, green algae, foraminifera linings and scolecodonts. The taxonomic list and the stratigraphical distribution of palynomorphs and foraminifera (benthic and planktic) are presented in Table $\mathbf{I}$ and Figure 2. Selected taxa of palynomorphs are illustrated in Figure 3.

The amorphous organic matter dominated the palynological assemblages, whereas phytoclasts and palynomorphs were subordinate, but phytoclasts is very well represented at all levels (Fig. 4). Terrestrial palynomorphs represented by spores and pollen grans were present in all levels, varying from $5 \%$ to $40 \%$ of the total assemblage. Well preserved angiosperm pollen grains comprise specimens of Chenopodiaceae, Compositae, Asteraceae and Onagraceae. Gymnosperm pollen grains reached a maximum of $40 \%$, while dinoflagellate cysts reached up $45 \%$ of the assemblage. The latter were mainly represented by species of

TABLE I

Abundance of genera of palynomorphs and foraminifera in the studied samples.

\begin{tabular}{c|c|c|c|c|c}
\hline Samples & Spores & $\begin{array}{c}\text { Pollen } \\
\text { grains }\end{array}$ & $\begin{array}{c}\text { Dinoflagellate } \\
\text { cysts }\end{array}$ & $\begin{array}{c}\text { Benthic } \\
\text { foraminifera }\end{array}$ & $\begin{array}{c}\text { Planktic } \\
\text { foraminifera }\end{array}$ \\
\hline 8 & 4 & 5 & 5 & 0 & 0 \\
\hline 7 & 1 & 2 & 2 & 0 & 0 \\
\hline 6 & 3 & 6 & 5 & 0 & 0 \\
\hline 5 & 2 & 4 & 4 & 0 & 0 \\
\hline 4 & 4 & 1 & 8 & 0 & 0 \\
\hline 3 & 4 & 8 & 7 & 6 & 0 \\
\hline 2 & 1 & 1 & 6 & 0 & 0 \\
\hline 1 & 0 & 1 & 7 & 20 & 8 \\
\hline
\end{tabular}




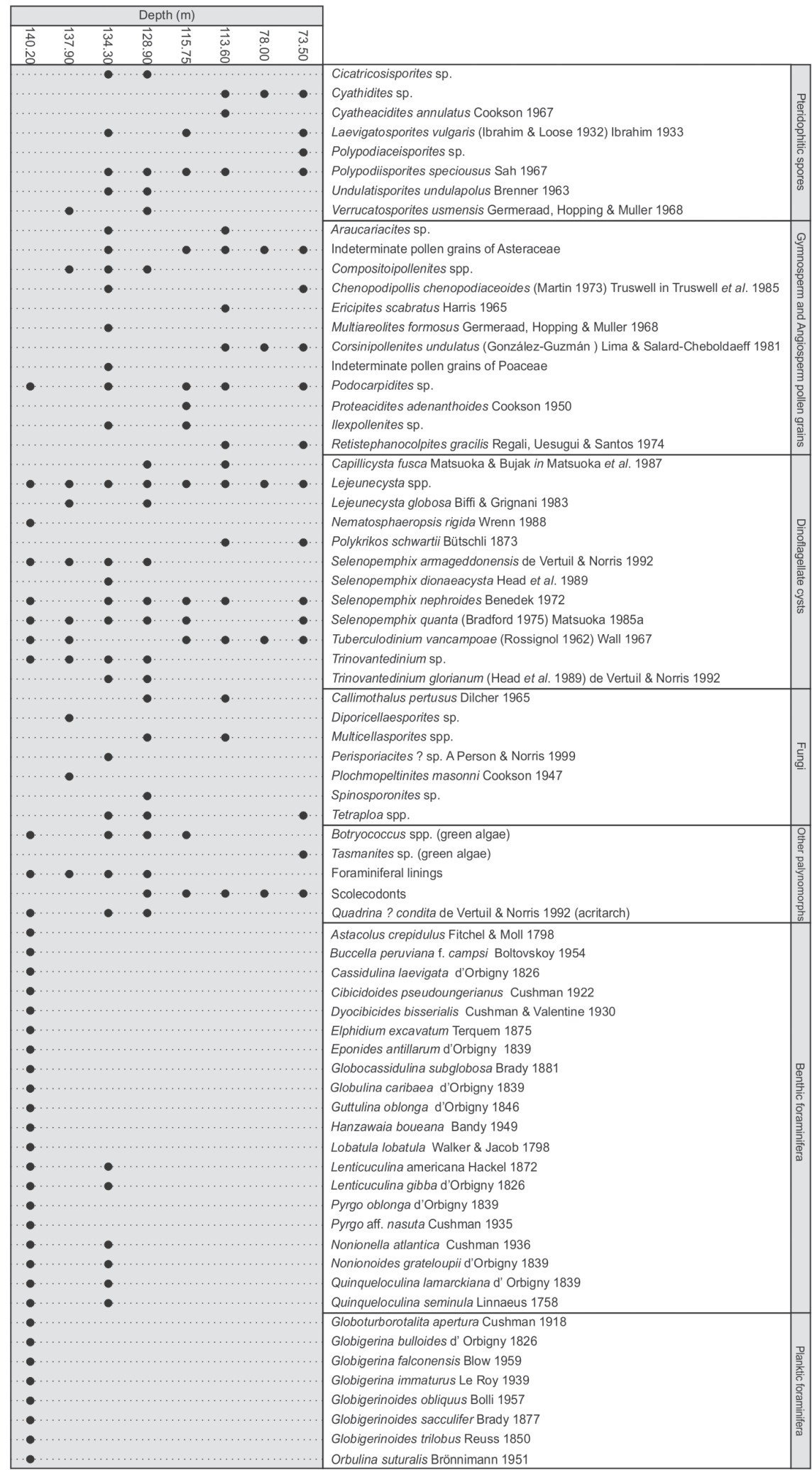

Fig. 2 - Stratigraphic distribution of the micropaleontological content (palynomorphs and foraminifera) in well 2-TG-96-RS. 


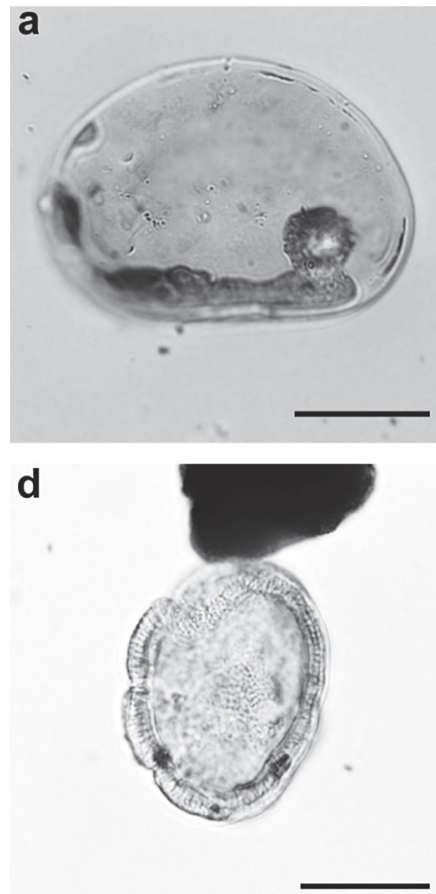

b

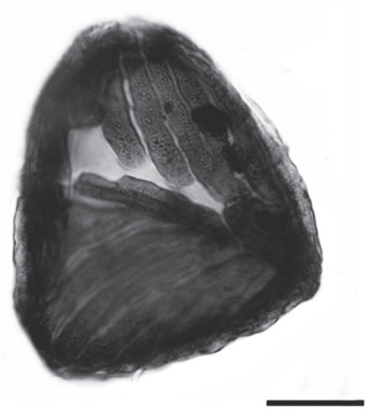

e

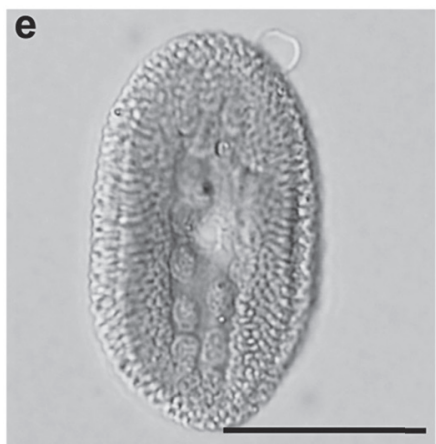

g

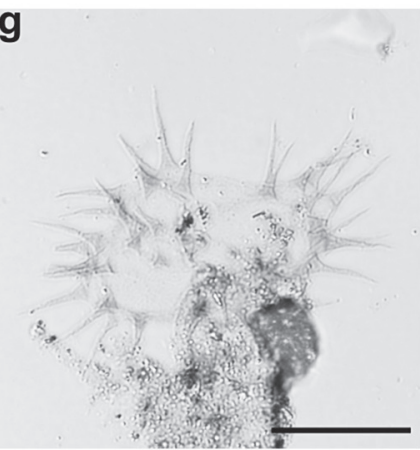

j

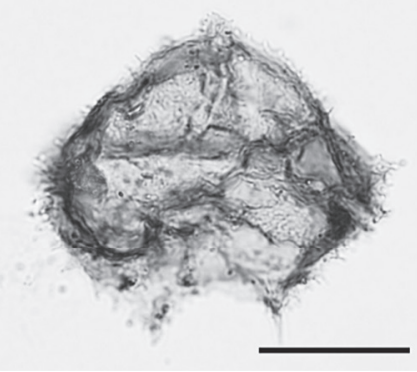

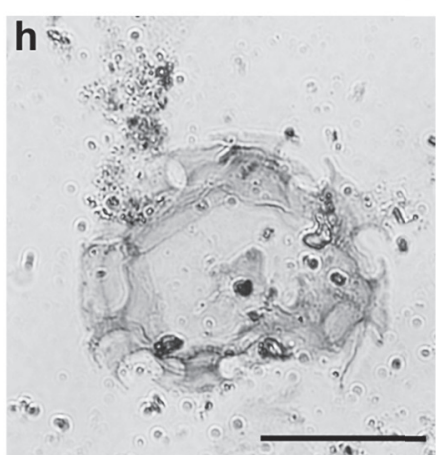

k

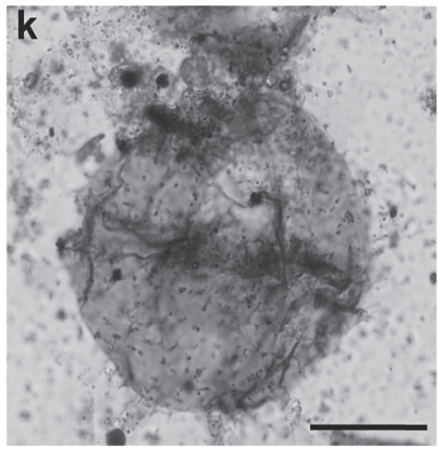

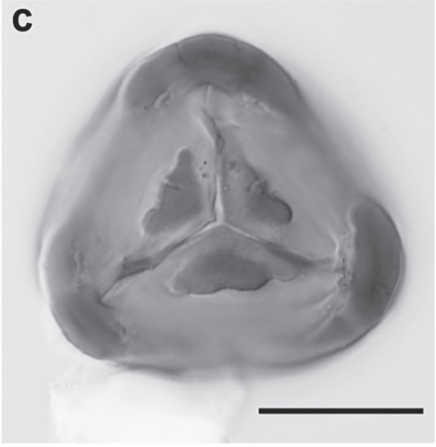
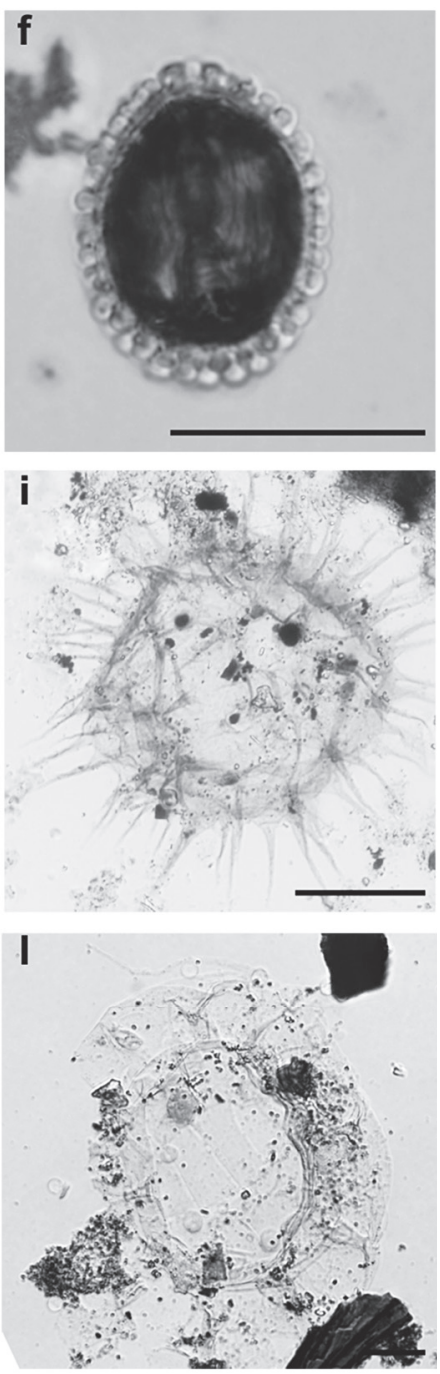

Fig. 3 - Selected palynomorphs recorded from well 2-TG-96-RS. (a) Laevigatosporites vulgaris (slide MP-P 5425; England Finder coordinate: N40-4); (b) Cicatricosisporites sp. 2 (5454; W60-1); (c) Cyatheacidites annulatus (5446; L56); (d) Retistephanocolpites gracilis (5403; T41-4); (e) Multiareolites formosus (5423; D30-1); (f) Ilexpollenites sp. (5431; M42-1); (g) Quadrina ? condita (5430; P30-3); (h) Selenopemphix armageddonensis (5452; N40); (i) Selenopemphix quanta (5617; K35-2); (j) Trinovantedinium glorianum (5423; O37-3); (k) Capillicysta fusca (5448; O57); (l) Tuberculodinium vancampoae (5414; P38). The scale bars represent $20 \mu \mathrm{m}$. 


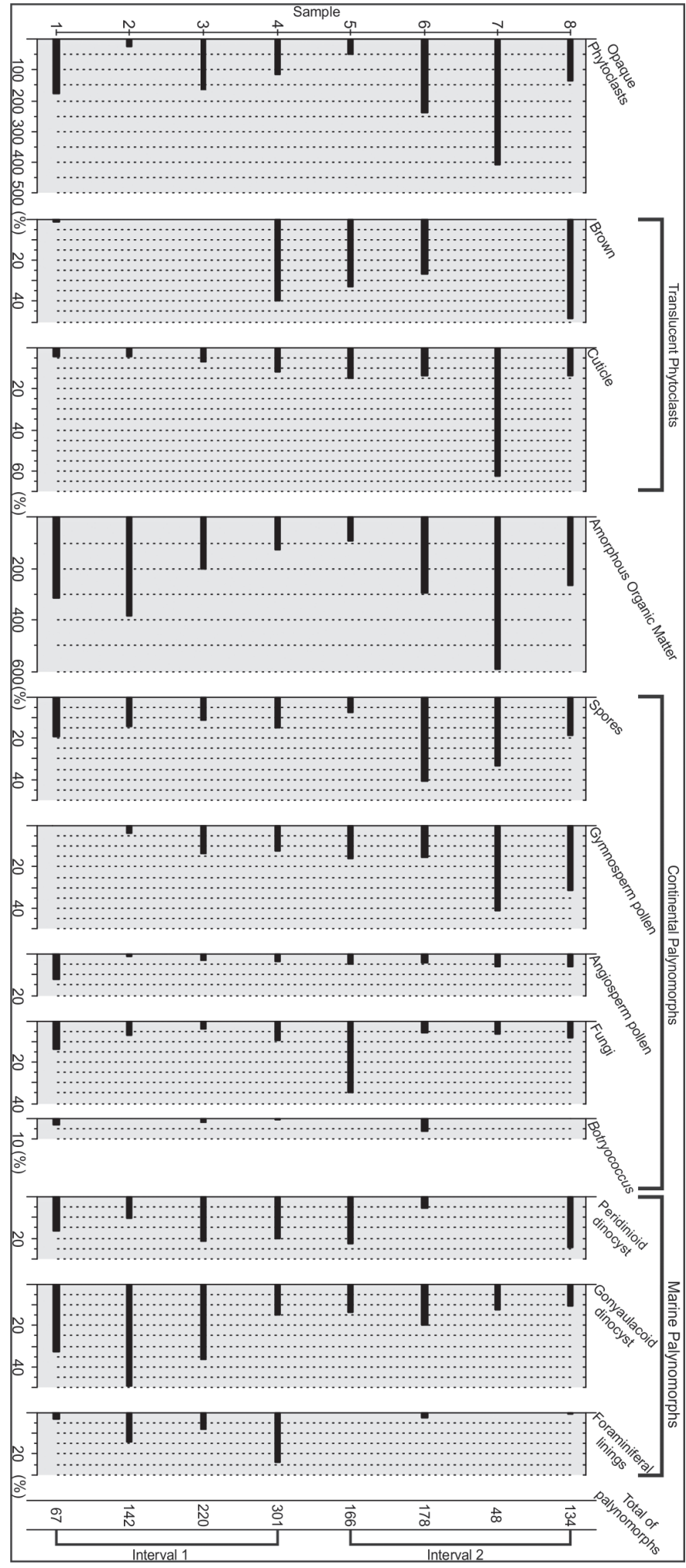

Fig. 4 - Relative frequencies (\%) of particulate organic matter along the study section of the well 2-TG-96-RS and the two paleoenvironmental intervals characterized here. 
Selenopemphix, Tuberculodinium, Lejeunecysta and Trinovantedinum. Unidentified spiral forms of foraminiferal linings reached up $25 \%$ of the association (Fig. 4).

Planktic foraminifera were recorded in only one sample, at the base of the studied section $(140.20 \mathrm{~m})$, where eight species were identified: Globigerina apertura, Globigerina bulloides, Globigerina falconensis, Globigerinoides trilobus, Globigerinoides immaturus, Globigerinoides sacculifer, Globigerinoides obliquus and Orbulina suturalis. Benthic foraminifera specimens were recorded in two levels (134.30 $\mathrm{m}$ and $140.20 \mathrm{~m})$, and are represented by 20 species, belonging to 17 genera (Fig. 2). Specimens of foraminifera are illustred in Figure 5.

Counting of benthic foramifera specimens by families (Cassidulinidae, Cibicididae, Elphidiidae, Eponididae, Gavelinellidae, Hauerinidae, Nonionidae, Polymorphinidae and Vaginulinidae), revealed two distinct intervals. The basal sample (140.20 m) was characterized by a high proportion of specimens of two families: Cibicididae $(33.70 \%)$ and Gavellinielidae $(32.30 \%)$. All other families presented low number of specimens at the $134.30 \mathrm{~m}$ sample (Fig. 6a).

Most of the foraminifera shells from well 2-TG96-RS were affected by partial dissolution. As a result, only one sample (at $134.30 \mathrm{~m}$ ) contained well preserved specimens suitable for ${ }^{87} \mathrm{Sr} /{ }^{86} \mathrm{Sr}$ analysis. The age assignment obtained from this sample indicates an age of $6.05 \mathrm{Ma}$, that corresponds to the Late Miocene (Messinian) (Fig. 6b).

\section{DISCUSSION}

BIOSTRATIGRAPHY

The age of the studied section was mainly based on the previously known stratigraphic ranges of palynomorphs and planktic foraminifera (Fig. 7 and 8). Ranges of dinoflagellate cysts were compiled from Head (1993), Williams et al. (2004), Powell and Brinkhuis (2004) and in the computer data base TAXON (R.L. Ravn, personal communication 2003). Stratigraphical distribution of terrestrial palynomorphs was derived from Regali et al. (1974a, b), Lima and Angulo (1990), Pinto and Regali (1990) and Garcia et al. (2008) (Fig. 7), while those used for planktonic foraminifera were based on Kennett and Srinivasan (1983) and Bolli and Saunders (1985) (Fig. 8); geochronology was calibrated according to Gradstein et al. (2012).

According to Williams et al. (2004), in the Northern hemisphere the first appearance of Trinovantedinium glorianum (Fig. 3j) (134.30 m and $128.90 \mathrm{~m}$ ) occurs at the top of the Serravalian stage (Middle/Late Miocene), whereas Selenopemphix armageddonensis (Fig. 3h) (140.20 m-128.90 m) is known from Late Miocene (Fig. 7). Quadrina ? condita (Fig. 3g) (140.20 m, 134.30 and $128.90 \mathrm{~m}$ ) has been recorded from Middle to Late Miocene (Kurita and Obuse 2003) and Capillicysta fusca (Fig. 3k) (128.90 and $113.60 \mathrm{~m}$ ) has its last occurrence (LO) in the Early Pliocene (Head 1993) (Fig. 7).

The species of sporomorphs Cyatheacidites annulatus, Multiareolites formosus and Retistephanocolpites gracilis were used in the zonal scheme established for the Meso- and Cenozoic Brazilian basins (Regali et al. 1974a, b). M. formosus (Fig. 3e) $(128.90 \mathrm{~m})$ presents its LO in the Late Miocene, and has been recognized in Miocene deposits throughout the Brazilian margin (Regali et al. 1974a, b) (Fig. 7). C. annulatus (Fig. 3c) $(113.60 \mathrm{~m})$ has been used as a marker in the Brazilian marginal and interior basin for the interval between the Early Miocene and the Pliocene (Regali et al. 1974a, b, Lima and Angulo 1990, Pinto and Regali 1990, Garcia et al. 2008); (Fig. 7). R. gracilis was recovered from deposits dated from the Early Miocene to the Pliocene (Fig. 3d) (113.60 m and $73.50 \mathrm{~m}$ ) (Regali et al. 1974a, b, Lima and Angulo 1990, Garcia et al. 2008) (Fig. 7).

The palynological content of samples collected between $140.20 \mathrm{~m}$ and $128.90 \mathrm{~m}$ indicated a Late Miocene age, due to the occurrence of the dinoflagellate cysts species $T$. glorianum and 


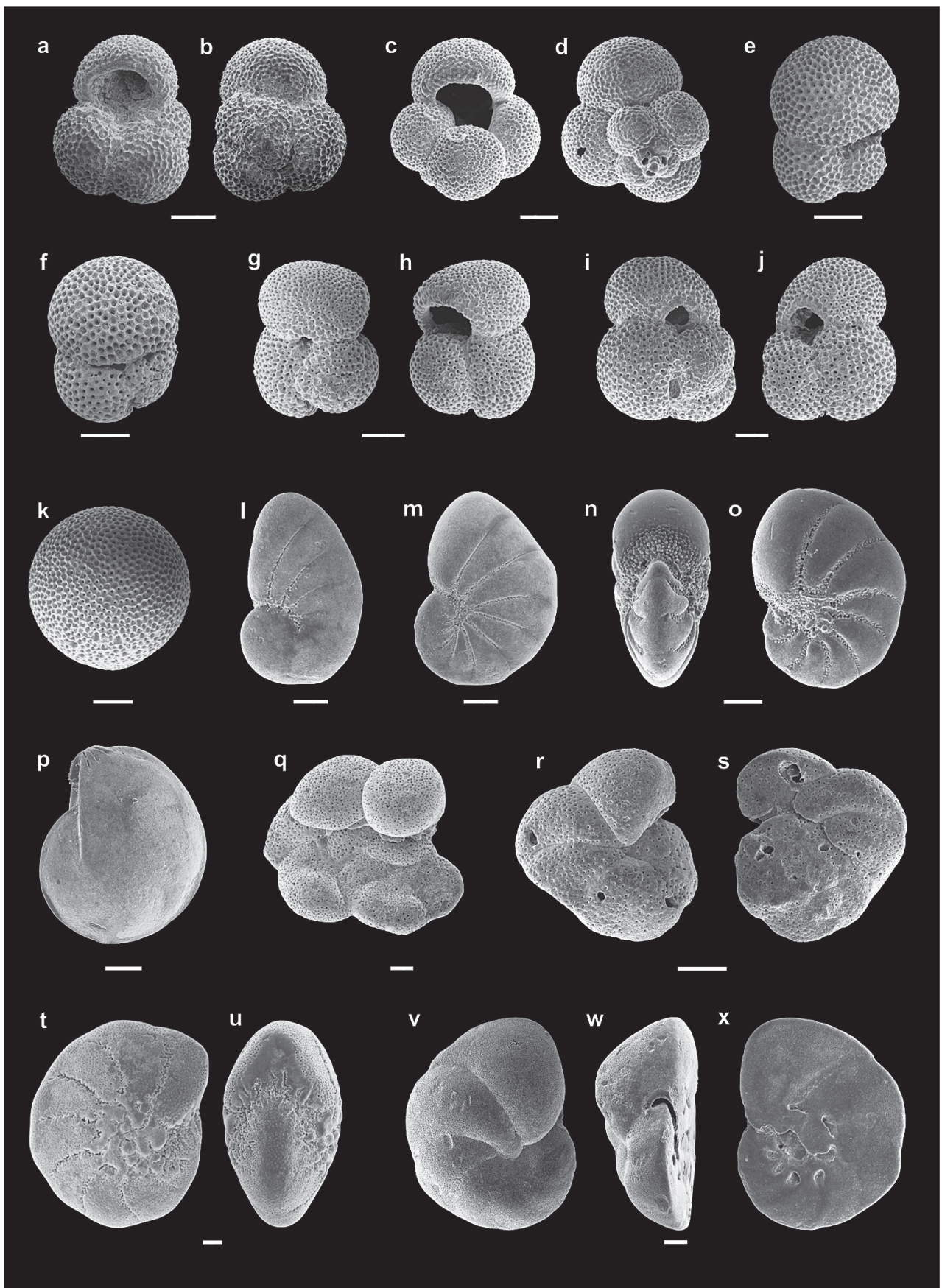

Fig. 5 - Selected foraminifera recorded from the well 2-TG-96-RS. (a-b) Globoturborotalita apertura (a) umbilical view, (b) spiral view; (c-d) Globigerina bulloides (c) umbilical view, (d) spiral view; (e-f) Globigerinoides trilobus (e) umbilical view, (f) spiral view; (g-h) Globigerinoides obliquus (g) umbilical view, (h) spiral view; (i-j) Globigerinoides sacculifer (i) umbilical view, (j) spiral view; (k) Orbulina suturalis; (l) Nonionoides grateloupi (spiral view); (m-o) Nonionella atlantica (m) apertural view, (n) umbilical view, (o) spiral view; (p) Lenticulina americana; (q) Dyocibicides bisserialis; (r-s) Lobatula lobatula (r) umbilical view, (s) spiral view; (t-u) Elphidium excavatum (t) umbilical view, (u) spiral view; (v-x) Hanzawaia boueana (v) spiral view, (w) lateral view, (x) umbilical view. The scale bars represent $100 \mu \mathrm{m}$. 


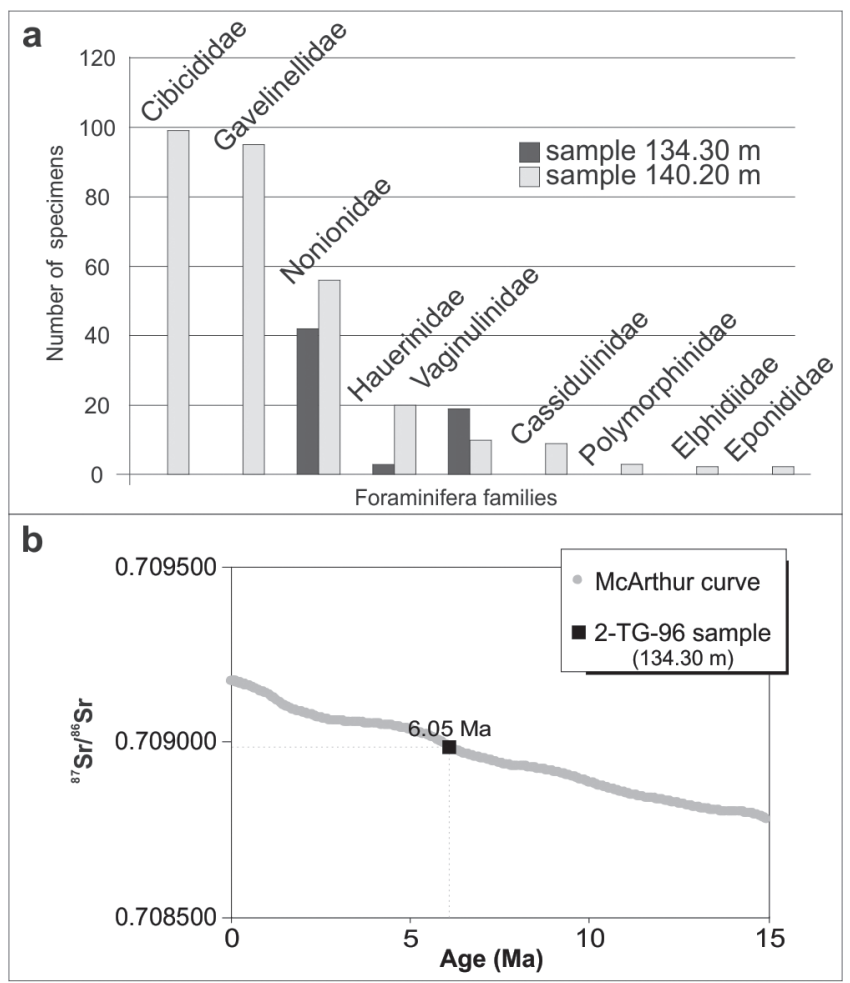

Fig. 6 - Number of specimens of benthic foraminifera per family in the samples $140.20 \mathrm{~m}$ and $134.30 \mathrm{~m}$ (a) and ${ }^{87} \mathrm{Sr} /{ }^{86} \mathrm{Sr}$ ratio and the obtained age for the analyzed sample (b).

S. armageddonensis and Q. ? condita (acritarch). This assignment is reinforced by the occurence of pollen grains attributed to M. formosus (Fig. 7). The simultaneous records of $C$. annulatus and $R$. gracilis, associated with the LO of C. fusca at $113.60 \mathrm{~m}$, indicate that the samples between 115.75 and $73.50 \mathrm{~m}$ are related to the Early Pliocene (Fig. 7). Based on this evidence, the samples analyzed from the well 2-TG-96-RS are considered to be from the Late Miocene to Early Pliocene in age (Fig. 6b and 8).

Based on the zonal schemes of Kennett and Srinivasan (1983) and Bolli and Saunders (1985), planktonic foraminifera recovered from the well 2-TG-96-RS indicates an age range from the Late Miocene to Early Pliocene, taking into account the concurrent presence of Globoturborotalita apertura (Fig. 5a, b) (Zone N16-N21 of Blow 1969) and Globigerinoides obliquus (Fig. 5g, h) (Zone N8 - N19 of Blow 1969) (Fig. 8). According to Chaisson and Pearson (1997), G. apertura ranges from 11.19 to $1.64 \mathrm{Ma}$ (Zone N14 to lower Zone N22).

\section{PALEOENVIRONMENTAL INTERPRETATION}

The paleoenvironmental interpretation of the studied interval is based on the integration of lithological and micropaleontological data, especially particulate organic matter (Fig. 4). The presence of foraminifera only in the lowest section indicates a shallowing a the environment. However, the continuous presence of pelecypods (Fig. 1c) and dinoflagellate cysts in the entire interval studied herein, indicates marine conditions throughout the study interval.

The section was subdivided into two intervals mainly based on the ratio between marine (dinoflagellate cysts and foraminiferal linings) 


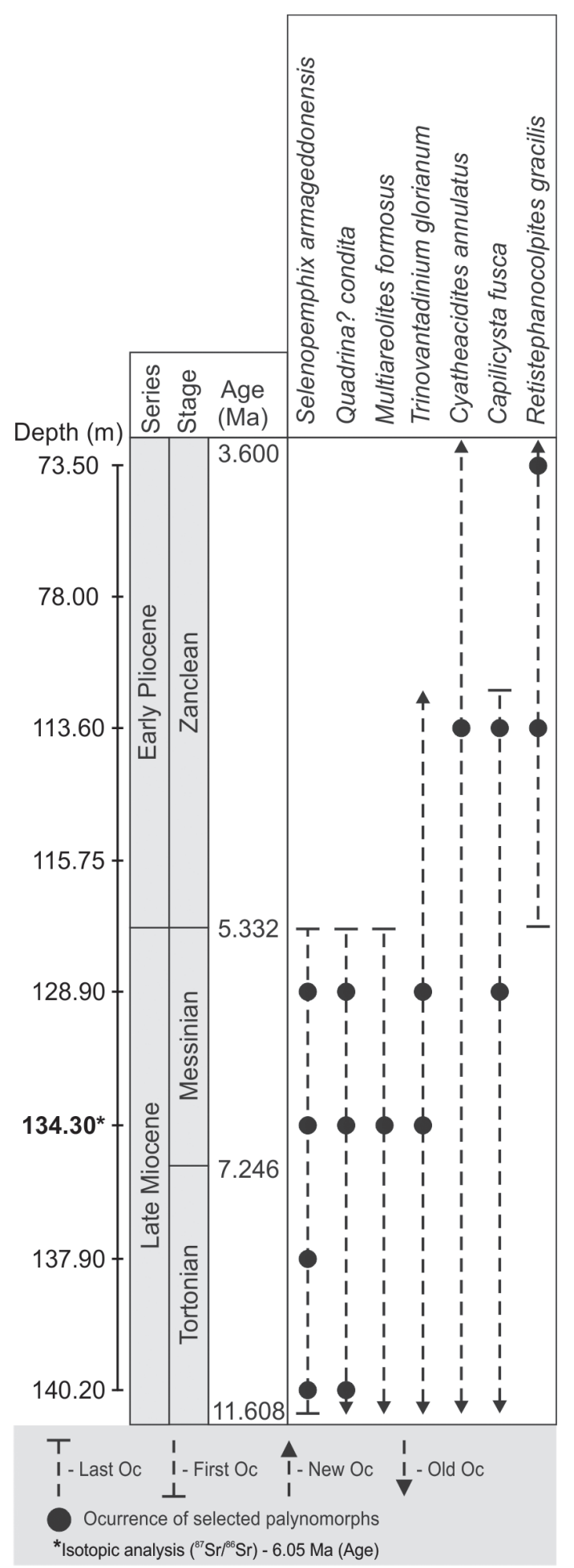

Fig. 7 - Stratigraphic range and occurrence of certain taxa of palynomorphs along the studied samples and their correspondent as discussed in the text. (Last Oc: Last Occurrence, First Oc: First Occurrence, New Oc: Newer Occurrence, Old Oc: Older Occurrence). and continental elements (sporomorphs), which shows inversely proportional distributions (Fig. 4). Counting was carried out to identify the organic matter compositional trend for each sample, changes in the relative abundance of certain particulate organic matter and palynomorph groups are linked to sea-level changes.

INTERVAL 1 (140.20 m-128.90 m) - LATE MIOCENE

In this interval(four samples), marine palynomorphs occur in high proportions (Fig. 4). Dinoflagellate cysts are dominant, up to $60 \%$ of the assemblage (at $137.90 \mathrm{~m}$ ). The percentage of this group decreases downward but maintains a frequency close to $35 \%$ (Fig. 4). Foraminiferal linings present peaks of abundance at $137.90 \mathrm{~m}(15 \%)$ and $128.90 \mathrm{~m}(25 \%)$.

Spores represent $20 \%$ of the palynomorphs assemblages at $140.20 \mathrm{~m}$, and about $15 \%$ at 137.90 m, $128.90 \mathrm{~m}$ and $134.30 \mathrm{~m}$ (Fig. 4). Gymnosperms pollen grains are absent in the basal sample, but occur in all overlying levels, varying from $5 \%$ to $20 \%$ of relative frequency (Fig. 4). Angiosperm pollen and fungal elements rarely occur, representing < $15 \%$ of the palynomorphs assemblage at 140.20 $\mathrm{m}$. Fresh water algae (Botryococcus) is very rare throughout the section, presenting less than $5 \%$ of the assemblage (Fig. 4).

Translucent phytoclasts occur only in the sample at $128.90 \mathrm{~m}(40 \%)$, including cuticles which have frequency from $5 \%$ to $15 \%$ upward in the section (Fig. 4). Opaque phytoclasts and amorphous organic matter are the predominant constituents of the particulate organic matter. Opaque phytoclasts are the most abundant particulate organic matter of terrestrial origin, while cuticles, spores, pollen and fungi occur subordinately (Fig. 4).

The abundance of partially degraded woody tissue (opaque phytoclast, translucent phytoclast and cuticles), which dominate the particulate organic matter, indicates fresh water input. Spores, pollen (angiosperm and gymnosperm) and fungal elements occur with low relative abundance 


\begin{tabular}{|c|c|c|c|c|}
\hline Age & 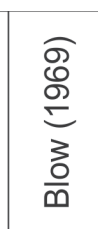 & \multicolumn{2}{|c|}{$\begin{array}{l}\text { Bolli and Saunders } \\
\qquad(1985)\end{array}$} & 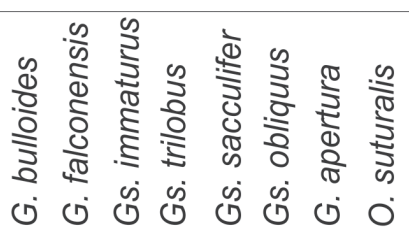 \\
\hline \multirow{4}{*}{ 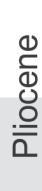 } & N21 & \multirow{2}{*}{$\begin{array}{l}\text { Globorotalia } \\
\text { miocenica }\end{array}$} & Gr. exilis & $\uparrow$ \\
\hline & N20 & & Gs. trilob.fistulosus & \\
\hline & N19 & \multirow{2}{*}{$\begin{array}{c}\text { Globorotalia } \\
\text { margaritae }\end{array}$} & Gr.mar.evolutae & \\
\hline & N18 & & Gr.mar.margaritae & \\
\hline \multirow{10}{*}{ 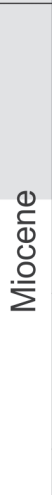 } & N17 & \multicolumn{2}{|c|}{ Globorotalia humerosa } & \\
\hline & N16 & \multicolumn{2}{|c|}{ Globorotalia acostaensis } & \\
\hline & N15 & \multicolumn{2}{|c|}{ Globorotalia menardii } & \\
\hline & N14 & \multicolumn{2}{|c|}{ Globorotalia mayeri } & \\
\hline & N13 & \multicolumn{2}{|c|}{ Globigerinoides ruber } & \\
\hline & $\mathrm{N} 12$ & \multicolumn{2}{|c|}{ Globorotalia fohsi robusta } & \\
\hline & N11 & \multicolumn{2}{|c|}{ Globorotalia fohsi lobata } & \\
\hline & N10 & \multicolumn{2}{|c|}{ Globorotalia fohsi fohsi } & \\
\hline & N9 & \multicolumn{2}{|c|}{ Globorotalia fohsi peripheroronda } & \\
\hline & N8 & \multicolumn{2}{|c|}{ Praerbulina glomerosa } & \\
\hline
\end{tabular}

Fig. 8 - Stratigraphic ranges of selected taxa of planktonic foraminifera occurrence in the sample $140.20 \mathrm{~m}$ and their biocronostratigraphical significance (zones and ages according to Bolli and Saunders 1985).

and diversity. Furthermore, these elements are generally poorly preserved, limiting a satisfactory taxonomic assess. Poor preservation and the low abundance of the terrestrial palynomorphs indicate a long distance between the depositional site and the source area.

The predominance of marine palynomorphs (dinoflagellate cysts and foraminiferal linings) and the high percentage of amorphous organic matter denote a marine depositional environment for this interval. Among the dinoflagellate cysts, predominance of gonyaulacoid forms (e.g., Nematosphaeropsis) suggests neritic environments (Edwards and Andrle 1992, Matsuoka 1992).

The benthic foraminifera assemblage is typical of nearshore environments (Yassini and Jones 1995, Scott et al. 2001). Most of the identified species are commonly found in recent coastal environments of the Brazilian margin (e.g., Closs and Barberena 1962, Semensatto-Jr and Dias-Brito 2004, Vilela et al. 2004, Burone and Pires-Vanin 2006). However, the presence of deeper dwelling forms such as the Cassidulina and Globocassidulina, together with the planktonic foraminifera probably indicates middle to outer neritic environments.

INTERVAL $2(115.75$ m-73.50m) - EARLY PLIOCENE

This interval comprise four samples and is characterized by an increase in continental particulate organic matter. Terrestrial palynomorphs consist mainly of bisaccate pollen (Podocarpaceae), which make up about $40 \%$ of sporomorphs in most samples. Angiosperm pollen grains belong to the families Asteraceae, Chenopodiaceae and Aquifoliaceae. Terrestrial palynomorphs are more frequent in this interval than in the underlying one. Spores present percentages between $9 \%$ and $40 \%$, angiosperm 
pollen $5 \%$, gymnosperm pollen between $15 \%$ and $40 \%$ and fungi between $15 \%$ and $35 \%$.

Dinoflagellate cysts represent from $5 \%$ to $25 \%$ of total palynomorphs, and are mainly composed of Lejeunecysta, Selenopemphix, Tuberculodinium and Polykrikos, which characterize an inner neritic environment (Wrenn and Kokinos 1986, Stover et al. 1996). Foraminiferal linings are locally recorded $(<5 \%$ at $113.60 \mathrm{~m})$ (Fig. 4).

All the samples in this section present high percentages of opaque phytoclasts and amorphous organic matter. Translucent phytoclasts (30\% - 45\%) and cuticle $(15 \%-60 \%)$ are very well represented (Fig. 4). The high frequencies of well preserved translucent phytoclasts including cuticles indicate short distance and non-turbulent transport from the continental source. The increase of continental palynomorphs is indicative of a strong fresh water input, probably in response to coastline progradation.

Reworked palynomorphs of Paleozoic and Mezosoic ages were assigned to genera Lunatisporites sp. (137.90 m), Vittatina sp. (78.00 m), Vittatina subsaccata Samoilovich 1963 (134.30 m), Limitisporites rectus Leschik 1956 (113.60 m) and Murosporaflorida (Balme) Pocock 1961 (115.75 $\mathrm{m}, 113.60 \mathrm{~m}, 73.50 \mathrm{~m})$. The latter is known from Upper Jurassic to Early Cretaceous deposits (Pocock 1961 and Burger 1996). All other specimens are very common in Gondwana Basins Permian deposits. With respect to the ocurences in Brazil, the pollen grains are recorded from Permiam biozones of the Paraná Basin (Souza and Marques-Toigo 2005). The occurrence of the Lunatisporites sp., Vittatina sp., Vittatina subsaccata, Limitisporites rectus suggest that the Paraná Basin Permian strata served as a source for the analyzed sediments.

The absence of foraminifera in the upper part of the section can be related to an upward shallowing in the section. On the other hand, the location of the well 2-TG-96-RS leads to the assumption that the complete dissolution of calcareous bioclasts is due to rain water infiltration. According to Morad et al. (2000), widespread areas of the continental shelf can be exposed by regressive events and, as a result, an increase in the recharging zones can occur and provide the input of precipitation.

\section{CONCLUSIONS}

This study presents biostratigraphic and paleoenvironmental interpretations based on Miocene and Pliocene palynomorph and foraminiferal associations from well samples. Additionally, an age assignment based on strontium isotopes $\left({ }^{87} \mathrm{Sr} /{ }^{86} \mathrm{Sr}\right)$ is presented. This data constitutes an integrated approach to study the Neogene deposits in the Pelotas Basin.

The palynological associations, recovered from the onshore well 2-TG-96-RS, indicate an age range from Late Miocene to Early Pliocene. The proposed palynological interpretation is corroborated by the ${ }^{87} \mathrm{Sr} /{ }^{86} \mathrm{Sr}$ isotopes data, which provided an age of $6.05 \mathrm{Ma}$ for the sample at $134.30 \mathrm{~m}$, corresponding to the Messinian stage. Furthemore, the planktonic foraminifera recovered from the lowermost sample indicates an age range from Late Miocene to Early Pliocene, supporting the age assignment based on dinoflagellate cysts.

Based on the palynological content, the studied section was subdivided into two intervals. Comparing these intervals, the decrease in frequency of dinoflagellate cysts and the absence of foraminiferal linings in the upper interval suggest deposition in more proximal conditions, in nearshore environments with a nearby fresh water influx. The major input of continental palynomorphs and woody tissue (opaque phytoclast, translucent phytoclast) corroborates with this interpretation. The section shows a gradual upward shallowing, probably related to the depositional environment.

The results obtained represent a contribution to the knowledge of the stratigraphic and paleoenvironmental evolution of pre-Quaternary coastal plain deposits from the Pelotas Basin. 
The studied section was deposited on top of Gondwana rocks, and can be considerd the oldest marine transgression recorded in the area. A shallowing upward trend is demonstrated in the section characterizing a marginal marine environment that was subsequently subjected to fresh water input during the Early Pliocene.

Paleozoic and Mesozoic palynomorphs were found in the upper portion of the studied interval and are interpreted to have been reworked from nearshore outcrops Gondwana strata. These preCenozoic deposits compose the paleorelief of the neighboring northern portions of the coastal plain of the Pelotas Basin in the Neogene.

\section{ACKNOWLEDGMENTS}

The authors would like to thank the Companhia de Pesquisa de Recursos Minerais (CPRM) for providing the samples and Petrobras for the SEM images. We are grateful to the Conselho Nacional de Desenvolvimento Científico e Tecnológico (CNPq proc. 132470/2010-1, 310727/2014-6), Agência Nacional do Petróleo, Gás Natural e Biocombustíveis (ANP) and Fundação de Amparo à Pesquisa do Estado do Rio Grande do Sul (FAPERGS proc. 1012119) for their financial support.

\section{RESUMO}

Este trabalho apresenta a integração da análise micropaleontológica (palinologia e foraminíferos) e de isótopos (razão ${ }^{87} \mathrm{Sr} /{ }^{86} \mathrm{Sr}$ ) de um intervalo selecionado do poço 2-TG-96-RS, perfurado na porção onshore da Bacia de Pelotas, Rio Grande do Sul, Brasil. Um total de oito amostras da seção entre 140,20 e 73,50 m de profundidade foi selecionado para análise palinológica, revelando associações de palinomorfos abundantes e diversificados. Espécies de esporos, grãos de pólen, cistos de dinoflagelados são os palinomorfos mais comuns encontrados. Foraminíferos calcáreos bentônicos e planctônicos foram recuperados dos dois níveis mais inferiores da seção (140,20 e 134,30 m). Com base na amplitude estratigráfica de espécies de cistos de dinoflagelados e esporomorfos, um intervalo de idade entre o Mioceno Superior e o Plioceno Inferior é atribuído. A idade relativa obtida a partir da razão ${ }^{87} \mathrm{Sr} r{ }^{86} \mathrm{Sr}$ em carapaças de foraminíferos calcários indica correspondência no Mioceno Final (Messiniano), corroborando o posicionamento bioestratigráfico realizado com palinomorfos. Interpretações paleoambientais baseadas na distribuição quantitativa dos componentes orgânicos (palinomorfos, fitoclastos e matéria orgânica amorfa) ao longo da seção e na associação de foraminíferos indicam ambiente marinho raso para a seção. Dois intervalos palinológicos foram reconhecidos com base na análise de palinofácies, relacionados a condições de plataforma média a externa $(140,20$ a $128,90 \mathrm{~m})$ e de plataforma interna (115,75 a 73,50 m).

Palavras-chaves: Micropaleontologia, Bioestratigrafia, Neógeno, Bacia de Pelotas.

\section{REFERENCES}

ANJOS GS AND CARREÑO AL. 2004. Bioestratigrafia (Foraminiferida) da sondagem 1-SCS-3B, Plataforma de Florianópolis, Bacia de Pelotas. Rev Bras Paleontol 7(2): 127-138.

Anjos-Zerfass GS, SouzA PA AND Chemale F JR. 2008. Biocronoestratigrafia da Bacia de Pelotas: estado atual e aplicação na geologia do petróleo. Rev Bras Geocienc 38(2-Supl): 47-62.

ARAi M, MASURE E AND LEMOS VB. 2006. Occurrence of a high-diversity Aptian microphytoplanktonic assemblage in Pelotas Basin (Southern Brazil): its implication for the Early Cretaceous history of the South Atlantic. In: Simpósio do Cretáceo do Brasil, 7, Serra Negra Rio Claro. Boletim de Resumos, p.12.

ASMUS HE AND BAISCH PR. 1983. Geological evolution of the Brazilian continental margin. Episodes 6(4): 3-9.

BAUERMANN SG, BEHLING H AND MACEDO RB. 2009. Biomas regionais e evolução da paisagem no Rio Grande do Sul com base em paleopalinologia. In: Ribeiro AM, Bauermann SG and Scherer CS (Eds), Quaternário do Rio Grande do Sul integrando conhecimentos. Porto Alegre SBP: 81-93 (Monografias da Sociedade Brasileira de Paleontologia). (Unpublished).

BLow 1969. Late middle Eocene to Recent planktonic foraminiferal biostratigraphy. In: Brönnimann P and Renz HH (Eds), Proc. First Int. Conf. Planktonic Microfossils, Geneva, 1967: Leiden (E.J. Brill) 1: 199-422.

Bolli HM AND SAUNDERS JB. 1985. Oligocene to Holocene low latitude planktic foraminífera. In: Bolli HM, Saunders JB and Perch-Nielsen K (Eds), Plankton Stratigraphy. Cambridge: Cam Univ Press, p. 155-262. 
Bueno GV, Zacharias AA, Oreiro SG, Cupertino JA, FALKENHEIN FUH AND MARTINS Neto MA. 2007. Bacia de Pelotas. B Geoci Petrobras 15(2): 551-559.

BURGER D. 1996. Mesozoic palynomorphs from the North West, offshore Western Australia. Palynology 20: 49-103.

BURONE L AND PIRES-VANIN AMS. 2006. Foraminiferal assemblages in Ubatuba Bay, south-eastern Brazilian coast. Sci Mar 70(2): 203-217.

Cainelli C AND Mohriak WU. 1999. Some remarks on the evolution of sedimentary basins along the eastern Brazilian continental margin. Episodes 22: 206-216.

CARreño AL, CoImBra JC AND Do CARMo DA. 1999. Late Cenozoic sea level changes evidenced by ostracodes in the Pelotas Basin, southernmost Brazil. Mar Micropaleontol 37: 117-129.

CARreño AL, CoImbra JC AND SANGUINetTI YT. 1997. Biostratigraphy of the Late Neogene and Quaternary ostracodes in the Pelotas Basin, Southern Brazil. Gaia 14: 33-43.

CASTILlo LLA, KAZMIERCZAK TS AND ChEMALE F JR. 2009 Rio Grande Cone tectono-stratigraphic model - Brazil: Seismic sequences. Ear Scie Res Jour 13(1): 40-53.

Ceolin D, Fauth G AND Coimbra JC. 2011. CretaceousLower Paleogene ostracods from Pelotas Basin, Brazil. Palaeobio and Palaeoenv 91(2): 111-128.

CHAISSON WP AND PEARSON PN. 1997. Planktonic foraminifer biostratigraphy at Site 925: Middle Miocene-Pleistocene. In: Schackleton NJ, Curry WB, Richter C and Bralowr TJ (Eds), Proc Ocean Drill Program Sci Results 154: 3-31. Available in: <http://www-odp.tamu.edu/publications $>$. Access: Jun 05, 2009.

Chang HK, Kowsmann RO, Figueiredo AMF And BENDER AA. 1992. Tectonics and stratigraphy of the East Brazil Rift System: An overview. Tectonophys 213: 97-138.

Closs D. 1967. Miocene planktonic foraminífera from Southern Brazil. Micropaleontol 13(3): 337-344.

Closs D. 1970. Estratigrafia da Bacia de Pelotas, Rio Grande do Sul. Iheringia 3: 3-76.

Closs D AND BARBERENA MC. 1962. Foraminíferos recentes das praias do litoral Sul-brasileiro - Arroio Chuí (RGS)Araranguá (SC). B Inst Cien Nat 18: 7-55.

COIMBra JC, CARREÑO AL AND ANJOS-ZERFASS GS. 2009 Biostratigraphy and paleoceanographical significance of the neogene planktonic foraminifera from the Pelotas Basin, southernmost Brazil. Rev Micropaleontol 52: 1-14.

CONCEIÇÃo JCJ, ZALÁN PV AND WOLFF S. 1988. Mecanismo, evolução e cronologia do rift Sul-Atlântico. B Geoci Petrobras 2(2-4): 255-265.

CONTRERAs J, ZÜHLKe R, BOWman S AND BechstÄDT T. 2010. Seismic stratigraphy and subsidence analysis of the southern Brazilian margin (Campos, Santos and Pelotas basins). Mar and Petrol Geol 27: 1952-1980.

DiAS JL, SAD ARE, FonTANA RL AND FEIJÓ FJ. 1994. Bacia de Pelotas. B Geoci Petrobras 8(1): 235-245.
EDWARDS LE AND ANDRLE VAS. 1992. Distribution of selected dinoflagellate cysts in modern marine sediments. In: Head MJ and Wrenn JH. Neogene and Quaternary Dinoflagellate Cyst and Acritarchs, Dallas: Am Assoc Stratigr Palynol Found, p. 259-288.

Fischer TV, SouzA PA, Helenes J AND ARAI M. 2013 Associações palinológicas do Paleógeno da Bacia de Pelotas (Poço BP-1, Brasil) e seu significado estratigráfico. Geociênc (São Paulo) 32(4): 677-695.

FONTANA RL. 1990. Investigações geofísicas preliminares sobre o Cone do Rio Grande, Bacia de Pelotas, Brasil. Acta Geol Leopold 13(6): 161-170.

FONTANA RL. 1994. Análise geotectônica e sismoestratigráfica da Bacia de Pelotas até a Plataforma de Florianópolis. In: $38^{\circ}$ Congresso Brasileiro de Geologia, Balneário Camboriú 1: 583.

GARCIA MJ, BISTRICHI CA, SAAD AR, CAMPANHA VA AND DE OLIVEIRA PE. 2008. Stratigraphy and paleoenvironments of the Tanque Basin, Southeastern Brazil. Rev Bras Paleontol 11(3): 147-168.

GOMIDE J. 1989. Bacia de Pelotas biocronoestratigrafia baseada em nanofósseis calcários. In: Congresso Brasileiro de Paleontologia, XI, Curitiba. Anais, p. 339-351.

GradsteIn FM, OGG JG, SchMitz MD AND OGG G. 2012. The Geologic Time Scale 2012: Boston, USA, Elsevier, 1176 p.

GRIMM EC. 1987. CONISS: A Fortran 77 program for strtigraphically constrained cluster analysis by the method of the incremental sum of square. Comput Geosci 13: 1335. Available in: <http://demeter.museum.state.il.us/pub/ grimm>. Access in: Jun 08, 2009.

GRIMM EC. 1990. Tilia and Tiliagraph: PC spreadsheet and graphics software for pollen data. INQUA, Commission for the Study of the Holocene, Working Group on DataHandling Methods: 5-7 (Newsletter 4).

Guerra RM, TOKUTAKE LR AND FAUTH G. 2012. Cretaceous calcareous nannofossils from Pelotas Basin, Brazil: Biostratigraphicand paleoecological inferences. Jour Sout Ame Ear Sci 36: 55-71.

HEAD MJ. 1993. A forum on Neogene and Quaternary dinoflagellate cysts. Palynology 17: 201-239.

Hermany G, Souza PA AND Torgan LC. 2013. Paleoecologia do sistema Pinguela-Palmital-Malvas, Holoceno da Bacia de Pelotas, RS, Brasil: uma abordagem focada na utilização de analyses multivariadas para obtenção de diatomáceas descritoras. Pesq Geoc 40(1): 31-49.

KenNetT JP AND SRINIVASAN MS. 1983. Neogene Planktonic Foraminifera: A Phylogenetic Atlas: Stroudsburg, PA (Hutchinson Ross), 265 p.

Koutsoukos EAM. 1982. Geohistória e paleoecologia das bacias marginais de Florianópolis e Santos. In: Congresso brasileiro de Geologia, XXXII, Salvador, Anais 5: 23692382.

Kowsmann RO, Francisconi O AND LEYDEN R. 1974 Refração sísmica marinha nas bacias de Pelotas, Santos Sul e na Plataforma de Torres. In: Congresso Brasileiro de Geologia, XXVIII, Porto Alegre, Anais 3: 283-295. 
KurITA H AND OBUSE A. 2003. Middle Miocene-Uppermost Lower Pliocene dinoflagellate cyst biostratigraphy, ODP leg 186 hole 1151A, off Sanriku Coast of Northern Japan, Northwestern Pacific. In: Suyehiro K et al. Proc Ocean Drill Program Sci Results 186: 1-19. Available in: <http://www-odp.tamu.edu/publications $>$. Access in: Jun 05, 2009.

Lima MR AND ANGUlo RJ. 1990. Descoberta de microflora em um nível linhítico da Formação Alexandra, Terciário do Estado do Paraná, Brasil. An Acad Bras Cienc 62: 357-371.

Lopes RP, Oliveira LC, Figueiredo AMG, Kinoshita A, BAFFA O AND SEKIGUCHI FB. 2010. ESR dating of pleistocene mammal teeth and its implications for the biostratigraphy and geological evolution of the coastal plain, Rio Grande do Sul, southern Brazil. Quater Inter 212: $213-222$.

MACEdo RB, SOUZA PA, BAUERMANN SG AND BORDIGNON SAL. 2010. Palynological analysis of a late Holocene core from Santo Antônio da Patrulha, Rio Grande do Sul, Southern Brazil. An Acad Bras Cienc 82: 731-745.

MATSUOKAK. 1992. Species diversity of Modern dinoflagellate cyst in surface sediments around the Japanese islands. In: Head MJ and Wrenn JH. Neogene and Quaternary Dinoflagellate Cyst and Acritarchs, Dallas: Am Assoc Stratigr Palynol Found, p. 33-53.

MCARTHUR JM AND HowARTH RJ. 2004. Strontium isotope stratigraphy. In: A Geological Timescale 2004. Gradstein FM, Ogg JG and Smith AG (Eds), CUP, Cambridge, p. $96-105$.

MCARTHUR JM, HowARTH RJ AND BAILEY TR. 2001. Strontium isotope stratigraphy: LOWESS Version 3. Bestfit line to the marine Sr-isotope curve for to $509 \mathrm{Ma}$ and accompanying look-up table for deriving numerical age. J Geol 109: 155-169.

Morad S, Ketzer JM And De Ros LF. 2000. Spatial and temporal distribution of diagenetic alterations in siliciclastics rocks: implications for mass transfer in sedimentary basins. Sediment 47: 95-120.

OJEDA HAO. 1981. Estrutura, estratigrafia e evolução das bacias marginais brasileiras. Rev Bras Geocienc 11(4): 257-273.

PINTO ADP AND REgali MSP. 1990. Plalinoestratigrafia dos sedimentos terciários da Bacia de Gandarela, Minas Gerais-Brasil. Rem: Rev Esc Minas 44(1): 10-15.

Pocock SAJ. 1961. Microspores of the genus Murospora, Somers, from Mesozoic strata of Western Canada and Australia. J Paleontol 35(6): 1231-1234.

Powell AJ AND BRinKhuis H. 2004. Figure 21.2 In: Lourens L, Hilgen F, Shackleton NJ, Laskar J and Wilson D. The Neogene Period. In: Gradstein F, Ogg J and Smith A (Eds), A Geological Time Scale 2004, Cambridge, Camb Univ Press, p. 409-440.

Premaor E, Souza PA, Arai M And Helenes J. 2010. Palinomorfos do Campaniano (Cretáceo Superior) da Bacia de Pelotas, Rio Grande do Sul: implicações bioestratigráficas e paleoambientais. Pesq Geoc 37(1): 63-79.
Regali MSP, Uesugui N AND SANTOS AS. 1974a. Palinologia dos sedimentos Meso-Cenozóicos do Brasil. Parte I. B Geoci Petrobras 17(3): 177-191.

Regali MSP, Uesugui N AND SAntos AS. 1974b. Palinologia dos sedimentos Meso-Cenozóicos do Brasil. Parte II. B Geoci Petrobras 17(4): 263-301.

SANGUINETTI YT. 1980. Bioestratigrafia (Ostracodes do Mioceno da Bacia de Pelotas, Rio Grande do Sul). Pesquisas 13: 7-34.

SCOTT DB, Medioli FS AND SCHAFER CT. 2001. Monitoring in Coastal Environments using Foraminifera and Thecamoebian indicators. Cambridge, Camb Univ Press, $177 \mathrm{p}$.

SEMENSATTO-JR DL AND DiAs-BRito D. 2004. Análise Ambiental de uma área parálica no delta do Rio São Francisco, Sergipe-Brasil, com base na sinecologia de foraminíferos e tecamebas (Protista). Rev Bras Paleontol 7(1): 53-66.

Silva WG, Souza PA, Helenes J AND Arai M. 2011. Palinomorfos Neogenos do poço 2-CA-1-RS, Bacia de Pelotas, Brasil: Significado bioestratigráfico e paleoecológico. Geol Usp Ser Cient 11(1): 149-169.

SimÕES MG, SILVA SAM, RodRIGUES SC AND COIMBRA JC. 2008. Braquiópodes (Rhynchonelliformea, Bouchardioidea) neógenos da Bacia de Pelotas (RS) e seu significado paleoambiental. Rev Bras Geocienc 38(4): 676-685.

Souza PA AND MARQues-Toigo M. 2005. Progress on the palynostratigraphy of the Permian strata in Rio Grande do Sul State, Paraná Basin, Brazil. An Acad Bras Cienc 77: 353-365.

StiCA MJ, ZALÁN PV AND FERRARI AL. 2014. The evolution of rifting on the volcanic margin of the Pelotas Basin and the contextualization of the Paraná-Etendeka LIP in the separation of Gondwana in the South Atlantic. Mar and Petrol Geol 50: 1-21.

Stover LE, Brinkhuis H, Damassa SP, De Verteuil LRJH, Monteil E, PARTRIdGe AD, POWELl AJ, Riding JB, SMElror M AND Williams GL. 1996. Chapter 19. Mesozoic-Tertiary dinoflagellates, acritarchs and prasinophytes. In: Jansonius J and Mcgregor DC (Eds), Palynology: priciples and applications, Dallas: Am Assoc Stratigr Palynol Found 2: 641-750.

THIESENZV. 1977. Bolivinitidae e Caucasinidae (Foraminifera) do Cenozóico Superior da Bacia de Pelotas, Rio Grande do Sul. Acta Geol Leopold 2(3): 8-32.

ThOMAS FCAND MURNEY MG. 1985. Techniques for extraction of foraminifers and ostracodes from sediment samples. Can Tech Rep Hydrogr Ocean Sci 54: 1-24.

Vilela CAG, BATISTA DS, BAPTISTA-NETO JÁ, CRAPEZ M AND MCALLISTER JJ. 2004. Benthic foraminifera distribution in high polluted sediments from Niterói Harbor (Guanabara Bay), Rio de Janeiro, Brazil. An Acad Bras Cienc 76: 161-171.

VILLWOCK JA. 1984. Geology of the Coastal Province of Rio Grande do Sul, Southern Brazil. A Synthesis. Pesquisas 16: 5-49. 
VILLWOCK JA AND TOMAZELLI LJ. 1995. Geologia Costeira do Rio Grande do Sul. Notas Técnicas 8: 1-45.

Williams GL, Brinkhuis H, Pearce MA, Fensome RA AND WEEGINK JW. 2004. Southern Ocean and global dinoflagellate cyst events compared: index events for the Late Cretaceous-Neogene. In: Exon NF et al. Proc Ocean Drill Program Sci Results 189: 1-98. Available in: <http:// www-odp.tamu.edu/publications>. Access: Nov 01, 2007.

Wood GD, Gabriel AM And Lawson JC. 1996. Chapter 3. Palynologycal techniques-processing and microscopy. In: Jansonius J and Mcgregor DC (Eds), Palynology: priciples and applications, Dallas: Am Assoc Stratigr Palynol Found 1: 29-50.
WRENN JH AND KOKINOS JP. 1986. Preliminary comments on Miocene through Pleistocene dinoflagellate cysts from De Soto Canyon, Gulf of Mexico. Am Assoc Stratigr Palynol Found, Contributions Series 17: 169-225.

YASSINI I AND JONES BG. 1995. Foraminiferida and Ostracoda from estuarine and shelf environments on the southeastern coast of Australia. The University of Wollongong Press, Wollongong, $484 \mathrm{p}$. 